\title{
The Kaizen philosophy in the aluminium products improvement
}

Prof. n. techn. i n. ekonom. dr hab. inż. Stanisław Borkowski, dr inż. Renata Stasiak-Betlejewska

Institute of Production Engineering, Czestochowa University of Technology, Al. Armii Krajowej 19 B, $42-200$ Częstochowa,

Poland, e-mail: renatastasiak@wp.pl

Ing. Nataša Náprstková, PhD.

Institute of Technology and Production Management, Jane Evangelista Purkyně University in Ústí nad Labem, Pateurova 7, 40001 Ústí nad Labem, Czech Republic

Kaizen strategy is the most important Japanese management concept. Supporters of this by all means an interesting management philosophy consider it as a basis for achieving success by the company. The analyzed company $X$ Stainless motivated by others companies market successes decided to deepen the knowledge of the Kaizen philosophy, which resulted in the implementation of this method of management in its ranks. The essence of Kaizen is to change ways of thinking and way of production management. Underlying this theory, there is the gradual but constant improvement of the status quo with the active involvement of every management employee and the rest of the company workers. Kaizen educates employees towards finding ways to better perform their duties. Performance of work is closely connected with the observance of standards and the introduction of small improvements in order to continue its improvement.

Keywords: Kaizen, quality, improvement

\section{References}

[1] BORKOWSKI S., Mierzenie poziomu jakości, pp. 7-14, Wyd. Wyższej Szkoły Zarządzania i Marketingu, Sosnowiec 2004, ISBN 83-89275-26-0.

[2] KOVAČÍKOVÁ A., LITVAJ I., ČEP R. Analýza uplatňování systému managementu kvality, Strojírenská technologie, XV december 2010/4, pp. 27-30 ISSN 1211-4162.

[3] KURILOVSKÝ T., PANDA A., JURKO J. Infrastructure How Support of Manufactruring Technology in the Context of Management Systems Requirements, Manufacturing Technology IX December 2009, pp. 119-122, ISSN 1213248-9.

[4] KVAPIL T., POHORALÝ M., Total Quality Management (TQM), Strojírenská technologie, X, 06/2005, No2, , pp. 2529, ISSN 1211-4162.

[5] NĚMEC M., Př́ínos metody Six Sigma ke zvyšování efektivity výrobního procesu, Strojírenská technologie, XVI july 2011/3, pp. 24-28, ISSN 1211-4162.

[6] SLANINA R., Dynamický klasifikační systém jako prostředek standardizace v oblasti technologické př́pravy výroby, Strojírenská technologie XI, july 2006/2, pp. 4-10, ISSN 1211-4162.

[7] ŠTŮSEK J., OSTROVSKÝ V., Strategické rozhodování v průmyslové firmě, Strojírenská technologie, XVI, july 2011/3, pp. 40-45 ISSN 1211-4162.

[8] ŠTU゚SEK J., ULRYCH L., Strategické rozhodováni v průmyslové firmě, Strojírenská technologie, XIV, December 2009/4, 33-38 ISSN 1211-4162.

[9] ZÍDKOVÁ H., Integrovaný management, Strojírenská technologie XI, march 2006/1, pp. 11-14, ISSN 1211-4162.

[10] ZRALÝ M., MÁDL J. Řizení technologických procesů v rámci controllingového řízení podniku, Strojírenská technologie, XI, december 2006/4, pp. 14-17, ISSN 1211-4162. 